\title{
RANCANGAN IMPLEMENTASI ANIMASI INTERAKTIF EDUKASI PENGENALAN SAMPAH BERDASARKAN JENISNYA
}

\author{
Adi Nurseptaji ${ }^{1}$, Rizki Tri Prasetio² \\ 1 Universitas Adhirajasa Reswara Sanjaya \\ e-mail: adinurseptaji@gmail.com \\ ${ }^{2}$ Universitas Adhirajasa Reswara Sanjaya \\ e-mail: rizki@ars.ac.id
}

\begin{abstract}
Abstrak
Saat ini ilmu pengetahuan tentang pentingnnya pengenalan limbah sampah sudah seharusnya diterapkan pada anak usia dini sehingga anak usia dini dapat mengetahui pengaruh yang akan dirasakan dari dampak penimbunan limbah sampah terhadap kesehatan dan juga dampak yang dapat dirasakan pada lingkungan. Penelitian ini bertujuan memberikan edukasi pembelajaran menggunakan aplikasi animasi interaktif yang lebih menarik sehingga tidak membosankan dalam hal memahami jenis sampah dan cara pengelolaanya. Metode pengembangan sistem waterfall tahapan pertama analisa kebutuhan untuk mendapatkan pemahaman seperti apa sistem yang akan dibutuhkan untuk user, desain sistem menggunakan storyboard untuk memberikan gambaran secara langsung tampilan animasi, implementasi dari desain menggunakan text editor adobe flash professional cs6, pengujian aplikasi menggunakan blackbox testing menguji keseluruhan fungsional pada aplikasi yang telah dirancang, maintenance/pemeliharaan pada software/hardware untuk memastikan tidak terjadi error kecil yang mungkin saja bisa terjadi dan tidak terdeteksi sebelumnya. Rancangan aplikasi ini menghasilkan media pembelajaran animasi interaktif mampu meningkatan minat tentang edukasi pembelajaran limbah sampah berdasarkan jenisnya karena aplikasi yang dirancangan menampilkan animasi gambar dan juga suara yang dapat menarik pada saat proses pembelajaran edukasi limbah sampah, sehingga edukasi yang disampaikan tidak membosankan dapat meningkatan motivasi serta semangat dalam hal pemahaman limbah sampah.
\end{abstract}

Kata kunci: Sampah, Waterfall, Storyboard, Animasi Interaktif, Adobe Flash

\begin{abstract}
Currently, knowledge about the importance of introducing waste waste should be applied to early childhood so that early childhood can find out the impact that will be felt from the impact of landfilling on health and also the impact that can be felt on the environment. This study aims to provide learning education using interactive animation applications that are more interesting so that they are not boring in terms of understanding the types of waste and how to manage them. The waterfall system development method is the first stage of needs analysis to get an understanding of what kind of system will be needed for users, system design using storyboards to provide a direct description of the animation display, implementation of the design using adobe flash professional cs 6 text editor, application testing using blackbox testing to test the whole functional in applications that have been designed, maintenance / maintenance on software / hardware to ensure that there are no small errors that might occur and were not detected before. The design of this application produces interactive animated learning media that can increase interest in waste waste education education based on its type because the application designed displays animated images and sounds that can be interesting during the waste education learning process, so that the education delivered is not boring and can increase motivation and enthusiasm. in terms of understanding waste waste.
\end{abstract}

Keywords: Trash, Waterfall, Storyboard, Interactive Animation, Adobe Flash. 


\section{Pendahuluan}

Kemajuan teknologi pada saat ini telah berpengaruh pada kehidupan manusia serta dapat memberikan ilmu pengetahuan yang sangat baik dan signifikan. Salah satu bagian penting dari kehidupan manusia yang tidak boleh terputus adalah ilmu pengetahuan dan juga pendidikan dengan hal tersebut ilmu pengetahuan dan pendidikan akan menciptakan pengaruh pada sumber daya manusia yang mampu membawa perubahan positif pada kehidupan manusia. Agar tujuan dari ilmu pengatahuan dan pendidikan dapat tercapai secara efektif sangat diperlukan dengan pemanfaatan dari kemajuan teknologi yang sudah ada pada saat ini (Rezeki \& Ishafit, 2017).

Pemanfaatan media sebagai sarana dalam proses pembelajaran dapat mendorong pengaruh psikologis yang dapat membangun rasa minat dan semangat yang baru untuk proses pembelajaran (Rasyid \& Rohani, 2018). Dari hal tersebut diperlukan suatu media sebagai alat bantu dalam proses pembelajaran yang bisa memotivasi kemudian diterapkan pada kalangan siswa baik didalam atau diluar ruangan yang berisi materi pembelajaran.

Dengan memanfaatkan sebuah media dapat berperan penting pada siswa dan berpengaruh pada perkembangan serta kecerdasan dalam hal proses pembelajaran. Kemajuan teknologi pada saat ini yang telah membawa banyak perubahan, sehingga diperlukan juga perubahan pada sistem pembelajaran yang lebih baik dengan pemanfaatan dari teknologi itu sendiri. Suatu media pembelajaran yang interaktif dapat memberikan sebuah materi yang bisa membawa pengaruh pada saat proses kegiatan pembelajaran karena materi yang disampaikan mempunyai sifat abstrak ataupun semu (Walhidayat, Yuhelmi, \& Devega, 2019).

Media interaktif suatu media kompleks yang kombinasikan serta bersatu secara berkala seperti teks, gambar, grafik, foto, video serta animasi, dari kumpulan berbagai unsur media tersebut terbentuk menjadi menarik sehingga bisa mengalihkan suatu perhatian dan melihatnya (Annisa, Saragih, \& Mursid, 2019).

Maka dari itu untuk menciptakan sebuah sistem pembelajaran dengan model yang lebih inovatif, sistem pembelajaran berbasis multimedia sangat berperan dengan memanfaatkan animasi sehingga dapat meningkatkan kualitas pada saat proses pembelajaran. Upaya peningkatkan kualitas pendidikan dan proses pembelajaran sudah seharusnya memberikan rasa aman dan nyaman agar siswa dapat terdorong untuk semangat dan terus belajar serta menambah wawasan ilmu pengetahuan (Kurniawarsih \& Rusmana, 2020).

Media digunakan sebagai perantara pengantar pengiriman pesan untuk penerima. Begipun untuk guru kepada siswa dalam mengajarkan dan menyamapaikan materi diperlukan suatu media yang digunakan sebagai alat bantu. Sebuah media tidak harus mahal yang akan diterapkan, media bisa dibuat seefesien mungkin sebagai alat penghubung yang dapat dengan mudah dipahami dan diterima untuk penyampaian materi pembelajaran dengan semaksimal mungkin oleh seorang guru pada siswa, yang telah dijelaskan bahwa media yang paling terpenting merupakan seorang pengantar. Untuk membangun kondisi pada siswa agar mampu memliki keterampilan dan pengatahuan serta sikap diperlukan sebuah media yang mengantarkan materi dan kejadian (Zaini \& Saputri, 2017).

Suatu media pembelajaran dapat memberikan hasil yang positif sehingga siswa menjadi lebih memiliki rasa semangat, dengan begitu siswa akan memiliki minat yang lebih terhadap proses pembelajaran serta dapat menambah kualitas dan meningkatkan mutu pada saat proses pembelajaran yang dapat berlangsung pada siswa. Beberapa rancangan media pembelajaran telah dilakukan suatu penelitian dan sukses, dan akan lebih baik media pembelajaran yang dirancang merupakan sebuah media pembelajaran yang lebih inovatif dan juga kreatif. Media pembelajaran dapat berpengaruh pada psikologi dan membangun motivasi serta kemauan minat yang baru bagi siswa saat proses kegiatan pembelajaran.

Yang dimaksud rancangan media tentunya dibuat agar dapat lebih mudah pada saat penyampaian materi pembelajaran dari guru pada siswa, sehingga tujuan pembelajaran pada siswa dapat tercapai dengan efisien serta mudah, maka dibutuhkan suatu media untuk pembelajaran yang lebih interaktif dan berbasis animasi multimedia untuk mendukung dan meningkatkan pembelajaran yang lebih efektif. 
Penulis mengkaji dan juga mengobservasi pada saat kegiatan proses pembelajaran antara guru dan siswa yang terjadi pada Pendidikan Anak Usia Dini (PAUD) Kelompok Bermain Bina Bangsa yang terdapat pada Kabupaten Purwakarta.

Saat ini ilmu pengetahuan tentang pentingnnya pengenalan limbah sampah sudah seharusnya diterapkan pada anak usia dini sehingga anak usia dini dapat mengetahui pengaruh yang akan dirasakan dari dampak penimbunan limbah sampah terhadap kesehatan dan juga dampak yang dapat dirasakan pada lingkungan.

Pada saat proses kegiatan pembelajaran yang berlangsung didapatkan masih adanya kendala yang dihadapi terutama pada saat penyampaian materi pembelajaran yang akan disampaikan oleh guru pada siswa mengenai limbah sampah beserta jenisnya karna belum adanya alat peraga untuk menyampaikan materi mengenai limbah sampah dan juga belum tersedianya tempat pembuangan sampah yang terpisah seperti sampah organik, anorganik dan limbah berbahaya beracun sehingga guru disaat memberi pemahanan pada anak tentang materi limbah sampah masih sangat kesulitan, permasalahan yang dihadapi lainnya penyampaian menggunakan pendekatan buku sehingga mudah robek dan kotor juga sulit untuk dibawa kemanapun.

Adanya kesulitan yang sering terjadi pada guru saat proses penyampaian materi pembelajaran yang sedang berlangsung pada siswa secara lisan dan juga tulisan, dimana siswa merasa bosan, terlihat jenuh kurang berminat dan juga kurang tertarik ketika memahami materi yang sudah disampaikan oleh guru sehingga mempengaruhi siswa dan guru menjadi kurang interaktif. Dan sudah seharusnya dilakukan pembaruan pada saat proses pembelajaran berlangsung.

Maka maksud dari hal tersebut penulis melakukan rancangan suatu media untuk proses pembelajaran dengan memanfaatkan sebuah software untuk membuat animasi adobe flash CS6, dengan memanfaatkan software adobe flash CS6 untuk pembuatan rancangan media pembelajaran yang lebih interaktif diharapkan dapat mempermudah siswa pada saat proses pembelajaran.

Dengan memanfaatkan software adobe flash yang memiliki kelebihan dapat mengkongkritkan materi pembelajaran, memberi pemahaman, terdapat desain yang bisa dibuat lebih inovatif serta menarik juga dapat dikombinasikan seperti font, gambar, warna, jenis animasi dan suara sebagai rancangan media pembelajaran sehingga menghasilkan proses pembelajaran yang lebih interaktif (Rustandi \& Mauliana, 2020).

Peran animasi multimedia yang dirancang lebih menarik dan juga interaktif sangat berpengaruh dalam memahami materi pembelajaran agar lebih baik dan juga meningkatkan kecerdasaran pada saat proses pembelajaran.

Dengan memanfaatkan media interaktif berpedoman dua dimensi untuk pembelajaran, sehingga anak akan lebih mudah mengerti tentang pentingnya edukasi sampah sesuai dengan jenis dan bagaimana upaya pengelolaanya (Regina, 2020).

Berdasarkan latar belakang serta permasalahan yang dihadapi dengan dirancangan animasi interaktif lebih menarik dalam tampilan dan tidak membosankan, animasi tersebut juga dapat memberikan pengetahuan dan wawasan kepada Pendidikan Anak Usia Dini (PAUD) Kelompok Bermain Bina Bangsa yang terdapat pada Kabupaten Purwakarta mengenai jenis-jenis sampah dan bagaimana langkah pengelolaannya.

\section{Metode Penelitian}

\section{A. Teknik Pengumpulan Data}

Penulis melakukan metode pengumpulan data, dengan melakukan proses observasi, wawancara pada Pendidikan Anak Usia Dini (PAUD) Kelompok Bermain Bina Bangsa yang terdapat pada Kabupaten Purwakarta, dan studi literatur untuk memperoleh data yang berkaitan dengan aplikasi yang akan dirancang. Berikut ini hasil pengumpulan data yang penulis dapatkan:

\section{Observasi}

Penulis mengobservasi dengan cara mengetahui proses belajar pada anak-anak dan mengartikan apa saja yang anak-anak pahami pada proses pembelajaran dikelas, dari tahap observasi ini penulis dapat melakukan pengembangan cara belajar agar anak-anak lebih produktif dan inovatif dalam hal proses belajar mengajar kedepannya.

2. Wawancara

Pada tahap pengumpulan data ini penulis melakukan wawancara tanya jawab dengan salah satu pengajar pada Pendidikan Anak Usia Dini (PAUD) Kelompok Bermain Bina Bangsa yang terdapat pada Kabupaten Purwakarta, agar mendapatkan data sebagai bahan rujukan untuk penelitian ini, 
penulis mengajukan pertanyaan terkait pendekatan yang dilakukan pada proses belajar mengajar dikelas dan minat belajar anak terutama kesadaran tentang limbah sampah pada lingkungan sekitar.

\section{Studi Pustaka}

Setelah melakukan tahapan pengumpulan data dengan cara observasi dan wawancara, kemudian penulis melakukan pengumpulan data dengan cara melakukan studi pustaka agar mendapatkan gambaran dengan membaca berbagai teori dari artikel ilmiah, buku dan internet yang berhubungan langsung tentang Animasi Interaktif Edukasi Pengenalan Sampah Berdasarkan Jenisnya sebagai bahan referensi dalam hal penulisan penelitian ini.

\section{B. Pemecahan Masalah}

Tahapan pemecahan masalah penulis memberikan penyelesaian terhadap permasalahan yang telah diuraikan diawal. Kemudian penulis membuat rancangan Animasi Interaktif Edukasi Pengenalan Sampah Berdasarkan Jenisnya dengan mengaplikasikan metode pengembangan sistem waterfall.

\section{Metode Pengembangan Sistem}

Pada tahapan ini penulis menggunakan metode waterfall dalam pengembangan sistem. Waterfall adalah salah satu metodologi pengembangan sistem dengan menggunakan Software Development Life Cycle (SDLC) siklus hidup untuk pengembangan perangkat lunak (software). Sekuensial linier atau alur hidup klasik merupakan proses dari metodologi waterfall. Dengan menggunakan prinsip berurutan mulai dari analisis, desain, pengkodingan, pengujian dan tahap pendukung dalam pengerjaan pengembangan sistem (Meilano \& Damanik, 2021).

1. Analisa Kebutuhan

Penulis melakukan proses analisa mengenai suatu kondisi yang dibutuhkan oleh sistem agar mendapatkan pemahaman seperti apa sistem yang akan dibutuhkan untuk user. Proses yang dilakukan pada tahapan ini menganalisa secara keseluruhan kebutuhan yang diperlukan dengan lengkap, yang selanjutnya dilakukan proses analisa sebagai penentuan solusi dalam perancangan animasi yang akan dibuat.

2. Desain

Pada tahap desain penulis membuat storyboard (penggambaran ide dari aplikasi yang akan dirancang) dengan desain yang akan memberikan gambaran secara langsung mulai dari tampilan animasi dan juga isi dari aplikasi yang akan dibuat.

3. Implementasi Perangkat Lunak

Penulis memanfaatkan software atau perangkat lunak untuk mendapatkan suatu hubungan perintah yang beraturan agar komputer bisa bekerja dalam pengelolaan data serta memperoleh informasi yang diperlukan untuk pengguna user. Perangkat lunak yang penulis manfaatkan pada proses pembuatan aplikasi ini adalah: Sistem Operasi Windows 7 (32/64 bit) / Windows 8 (32/64 bit), Bahasa pemrograman Action Script 2.0, Text editor Adobe flash professional cs6.

4. Implementasi Perangkat Keras

Adapun implementasi perangkat keras yang penulis manfaatkan untuk mengoptimalkan kinerja dari software dan aplikasi yang akan dirancang. Asosiasi antara perangkat lunak dan perangkat keras dalam pengembangan aplikasi sangat diperlukan agar hasil yang diharapkan dari sistem komputer itu sendiri menjadi lebih maksimal sehingga berdampak pada pengguna sistem. Perangkat keras yang penulis gunakan pada rancangan aplikasi sebagai berikut ini: Central Processing Unit (CPU): Processor Inter® Pentium® Dual Core, Random Access Memory (RAM) Double Data Rate 2 (DDR2) 2GB, Hard Disk 250 GB, Mouse: Mouse USB / Mouse Wireless, Liquid Crystal Display (LCD): Resolusi layar minimum 14.

5. Testing

Setelah selesai melakukan proses tahapan implementasi program, selanjutnya masuk pada tahapan testing dan pengujian. Pada tahapan ini penulis melakukakan pengujian secara keseluruhan pada aplikasi yang telah dirancang. Penulis melakukan pengujian aplikasi dengan cara menggunakan blackbox testing, fokus pada tahapan pengujian blackbox testing ini meliputi keseluruhan fungsional kesamaan yang diharapkan oleh pengguna pada aplikasi yang dirancang. Langkah yang dilakukan pada tahapan ini dengan melakukan test case agar tidak terdapat kesalahan (error) dan kemudian menguji fungsi-fungsi yang terdapat pada aplikasi.

6. Operation dan Maintenance

Pada tahapan implementasi dimana program sudah melalui proses pengujian, dalam kondisi ini program telah siap dan dapat dimanfaatkan untuk pengguna atau user pada Pendidikan Anak Usia Dini (PAUD) Kelompok Bermain Bina Bangsa, 
khususnya dengan penerapan yang telah dirancang, dimulai dari tahapan rancangan analisa kebutuhan, desain, code generation kemudian tampilan user interface (UI) yang sudah masuk pada proses tahapan pengujian.

Setelah melewati tahapan ini sistem dapat digunakan oleh pengguna atau user dan kemudian sistem dapat dimanfaatkan secara luas.

Kemudian untuk maintenance/pemeliharaan pada software/hardware sangat diperlukan secara berkala untuk memastikan tidak terjadi error kecil yang mungkin saja bisa terjadi dan tidak terdeteksi sebelumnya. Pada tahapan maintenance/pemeliharaan juga diperlukan kritik dan juga saran yang membangun dari user agar software dapat lebih baik lagi, karena software yang dirancang tentu akan mengikuti perkembangan sesuai dengan kebutuhan user. Peningkatan pada fitur-fitur yang terdapat pada software yang sebelumnya tidak ada dapat ditambahkan, maintenance/pemeliharaan juga dapat terjadi pada sistem operasi atau perubahan perangkat lainnya yang bersifat external sesuai dengan kebutuhan pengembangan yang bisa saja dilakukan.

\section{Hasil dan Pembahasan}

Pada bagian ini menjelaskan hasil rancangan dan implementasi dari aplikasi yanbg dibuat

\subsection{Analisa Kebutuhan Pengguna}

Pada tahapan ini penulis melakukan analisa apa saja yang dibutuhkan oleh pengguna yang terdapat pada aplikasi yang meliputi sebagai berikut ini:

1. Pengguna dapat mengenal limbah sampah berdasarkan jenis-jenisnya seperti limbah sampah organik, limbah sampah non-organik, dan limbah sampah bahan berbahaya dan beracun (B3).

2. Pengguna dapat mengetahui bagaimana cara pengelolaan limbah sampah agar tidak mencemari lingkungan serta pengelolaan limbah sampah yang akan menghasilkan nilai jual.

3. Pengguna dapat mengetahui dampak yang akan dirasakan dari penimbunan limbah sampah baik itu dampak yang dirasakan pada lingkungan dan juga dampak yang dirasakan pada kesehatan.

4. Untuk melatih ingatan pada pengguna aplikasi ini terdapat latihan soal tentang limbah sampah dan cara mengelolanya.

\subsection{Desain}

\section{Stroyboard}

Rancangan storyboard ini untuk mengilustrasikan runtutan keseluruhan kegiatan suatu isi jalan cerita yang divisualkan dan berpedoman pada media yang dirancang. Fungsi dari storyboard ini juga sebagai uraian dan suatu langkah yang kemudian diilustrasikan, dengan memadukan keseluruhan objek yang ada pada media serta tautan kedalam suatu langkah yang lebih lanjut (Robby Andry, 2020).

Berikut ini rancangan skenario storyboard aplikasi interaktif pengenalan jenis sampah yang penulis rancang.

Tabel 1. Stroyboard Menu Utama

\begin{tabular}{|c|r|r|}
\hline Scene & Desain & \multicolumn{1}{|c|}{ Isi } \\
\hline Menu & Mengenal Jenis Sampah & - Button \\
Utama & Mulai \\
& Mutui & \\
& & - Button \\
& & Exit \\
\hline
\end{tabular}

Pada tabel 1. menerangkan tampilan menu utama mengenal jenis sampah pada button mulai memuat atau mengarah pada menu selanjutya yaitu terdapat menu awalan yang memuat berbagai button pengertian jenis sampah, dampak limbah sampah, cara pengelolaan sampah dan latihan soal, untuk mengakhiri aplikasi ini terdapat button exit.

Tabel 2. Stroyboard Menu Awal

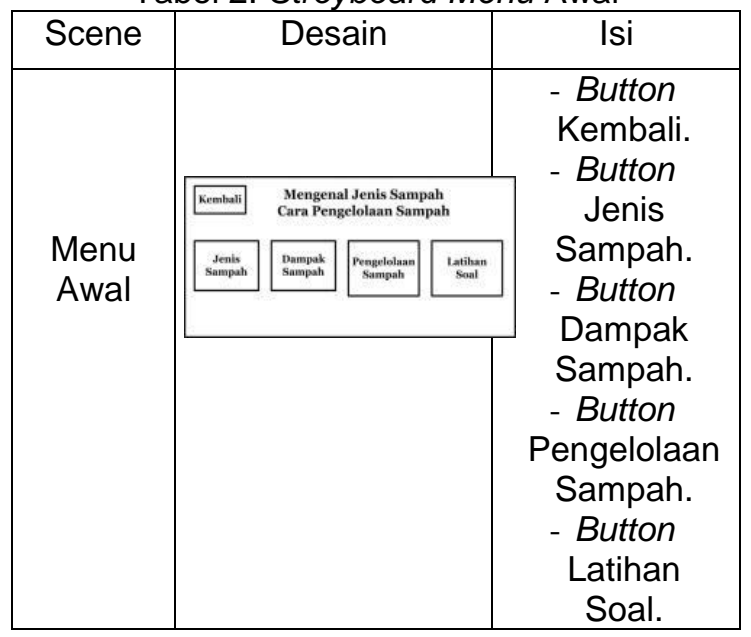

Pada tabel 2. menerangkan tampilan halaman awal ketika menekan button mulai, dimana pada tampilan ini terdapat button kembali pada menu utama, terdapat button jenis sampah, button dampak sampah, 
button pengelolaan sampah dan button latihan soal.

Tabel 3. Stroyboard Menu Pengertian Jenis

\begin{tabular}{|c|c|c|c|}
\hline Scene & & Desain & Isi \\
\hline \multirow{4}{*}{$\begin{array}{c}\text { Menu } \\
\text { Pengertian } \\
\text { Jenis }\end{array}$} & \multirow{2}{*}{\multicolumn{2}{|c|}{$\begin{array}{c}\text { Pengertian } \\
\text { Jenis sampah }\end{array}$}} & - Button \\
\hline & & & - Button \\
\hline & Kembali & & Organik. \\
\hline & & & $\begin{array}{c}\text { Anorganik } \\
\text { Sampah. } \\
\text { - Button } \\
\text { Sampah } \\
\text { B3. }\end{array}$ \\
\hline
\end{tabular}

Pada tabel 3. menerangkan tampilan berbagai button pengertian jenis sampah setelah menekan button jenis sampah pada halaman sebelumnya, pada tampilan ini terdapat button sampah organik, button sampah anorganik, button sampah B3 dan button kembali pada halaman awal.

Tabel 4. Stroyboard Tampilan Pengertian Sampah dan Pengelolaan Sampah.

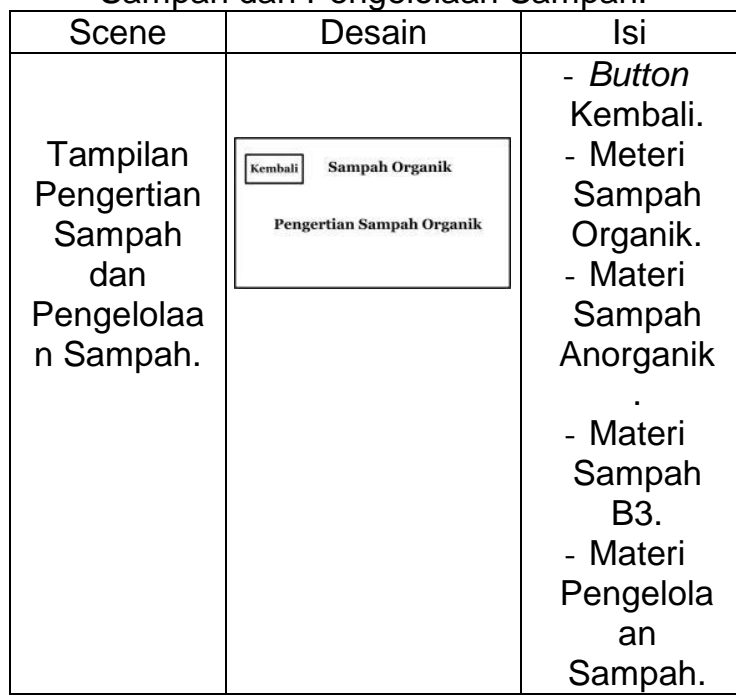

Pada tabel 4. menerangkan tampilan halaman materi sampah organik, pada tampilan ini juga menampilkan materi sampah anorganik, materi sampah B3 dan materi pengelolaan sampah, pada tampilan halaman ini terdapat button kembali pada menu awal.
Tabel 5. Stroyboard Tampilan Latihan Soal

\begin{tabular}{|c|c|c|c|c|}
\hline \multirow{6}{*}{$\begin{array}{c}\text { Tampila } \\
n \\
\text { Latihan } \\
\text { Soal }\end{array}$} & \multicolumn{3}{|c|}{ Desain } & Isi \\
\hline & \multicolumn{3}{|c|}{ Latthan Soal 1} & \\
\hline & Prilihan jumatan & & & $\begin{array}{c}\text { Button } \\
\text { next. }\end{array}$ \\
\hline & $\begin{array}{l}\text { Pillhan jamathan } \\
\text { brears sulth }\end{array}$ & & & J atianan \\
\hline & 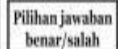 & 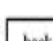 & 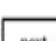 & pilihan \\
\hline & & & & benar/sala \\
\hline
\end{tabular}

Pada tabel 5. menerangkan tampilan halaman latihan soal, yang menampilan latihan soal, button pilihan jawaban benar/salah, button next untuk latihan soal selanjutnya, button back untuk kembali ke latihan soal sebelumnya.

\section{State Transition Diagram (STD)}

State Transition Diagram ini bertujuan untuk menggambarkan pemodelan software atau suatu alur yang ada pada aplikasi. gambaran dari tahapan pemodelan ini bertujuan untuk mendukung dan menguraikan pada desain model media pembelajaran yang dirancang (Setiawan Mardian D \& Wiguna Wildan, 2020).

Desain pemodelan pada media pembelajaran edukasi pengenalan limbah sampah yang penulis rancang pada penelitian ini yang terdapat pada Gambar 1 .

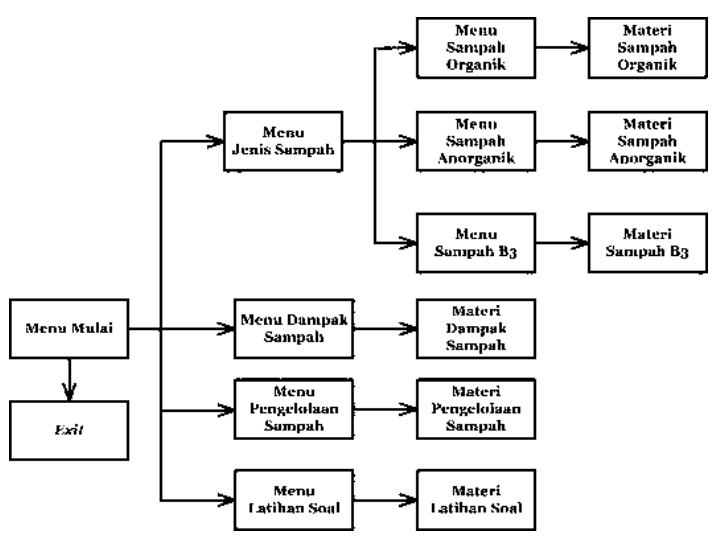

Gambar 1. State Transition Diagram

Pada Gambar 1. menerangkan suatu proses yang menggambarkan alur dan skenario yang terdapat pada media pembelajaran pengenalan jenis sampah, pada alur gambaran skenario diatas menampilkan transisi pada saat aplikasi pertama kali dibuka, transisi halaman yang dijalankan yaitu: 
a. Menu Mulai, pada halaman menu mulai terdapat button mulai, yang mengarah pada halaman menu awal aplikasi, terdapat button exit untuk mengakhiri aplikasi.

b. Menu Jenis Sampah, mengarah pada halaman pengertian jenis-jenis sampah dan akan menampilkan materi-materi seperti pengertian sampah organik, pengertian sampah anorganik, pengertian sampah B3.

c. Menu Dampak Sampah, mengarah pada halaman materi dampak dari penimbunan limbah sampah.

d. Menu Pengelolaan Sampah, mengarah pada halaman materi cara mengelola sampah organik, anorganik dan sampah B3.

e. Menu Latihan Soal, mengarah pada latihan soal, pada materi latihan soal yang disajikan berupa materi-materi yang telah dipaparkan pada halaman sebelumnya mengenai limbah sampah, pilihan jawaban akan menampilkan benar atau salah.

3. User Interface

Terdapat tampilan antarmuka pada aplikasi yang bisa disebut sebagai user interface (UI). User Interface sebagai komponen yang bertugas dan tidak bisa dipisahkan pada aplikasi untuk penghubung interaksi antar aplikasi dan pengguna agar bisa dipahami dengan mudah (Anggara, Harianto et al., 2021). Berikut ini tampilan user interface dari aplikasi pengenalan jenis sampah yang penulis rancang.

a. Tampilan halaman utama.

Tampilan halaman utama pada saat pertama kali pengguna membuka aplikasi, pada halaman ini terdapat button mulai untuk menuju kehalaman berikutnya untuk memulai materi pembahasan tentang limbah sampah, pada halaman utama ini juga tedapat button exit yang berfungsi untuk mengakhiri aplikasi.

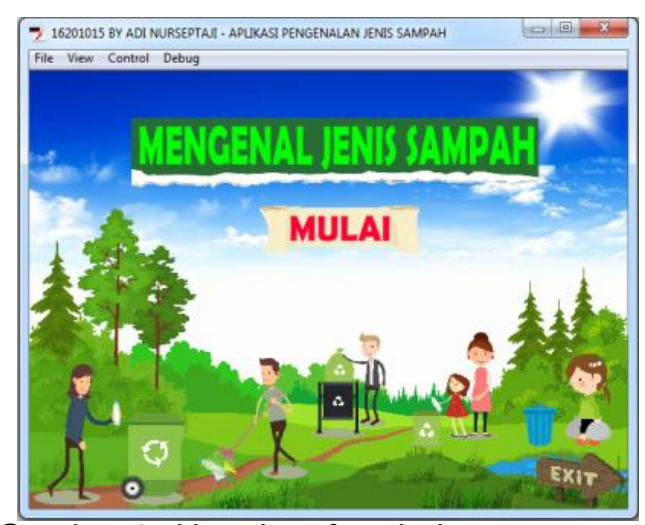

Gambar 2. User Interface halaman utama

b. Tampilan halaman awal.

Pada tampilan ini akan muncul ketika pengguna menggunakan button mulai, pada tampilan ini terdapat button jenis sampah yang akan menampilkan materi jenis-jenis sampah, button dampak sampah yang akan menampilkan materi dampak sampah, button pengelolaan sampah yang akan menampilkan materi pengelolaan sampah kemudian button latihan soal yang akan menampilkan berbagai latihan soal menganai materi limbah sampah.

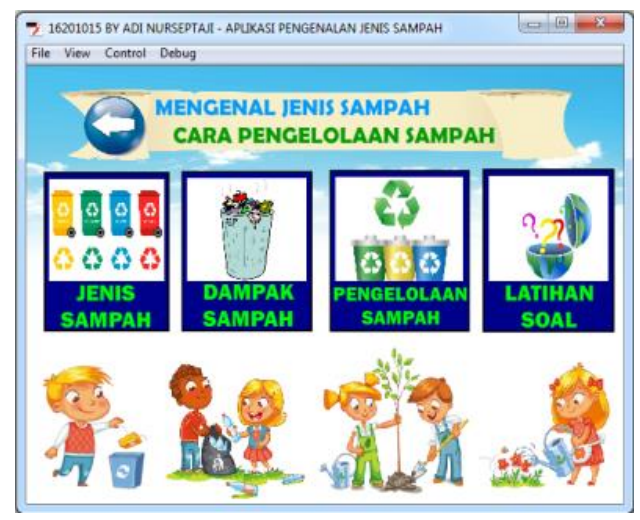

Gambar 3. User Interface menu halaman awal

c. Tampilan halaman menu materi jenis sampah.

Tampilan ini akan muncul ketika menggunakan button jenis sampah pada halaman sebelumnya dimana pada halaman ini terdapat button mengenai materi sampah organik, button mengenai materi sampah anorganik, button mengenai materi sampah B3. 


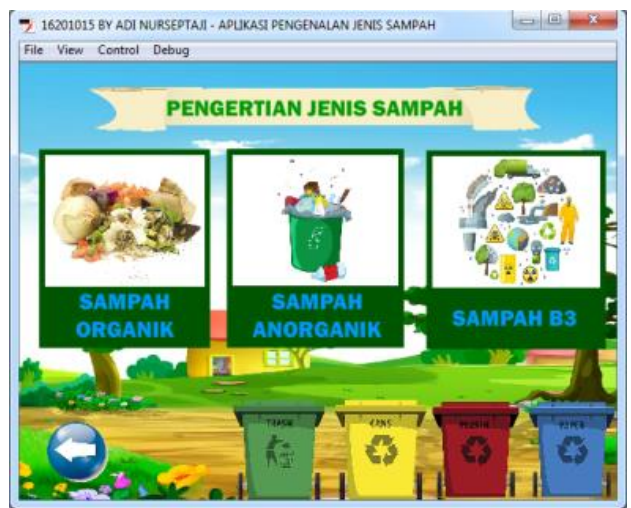

Gambar 4. User Interface menu pengertian sampah

d. Tampilan halaman latihan soal.

Pada halaman ini menampilkan latihan soal, yang akan muncul ketika pengguna memilih menu latihan soal, pada halaman latihan soal ini disertai dengan pilihan beberapa jawaban, halaman ini juga terdapat button next untuk menuju soal berikutnya and button back untuk kembali pada latihan soal sebelumnya.

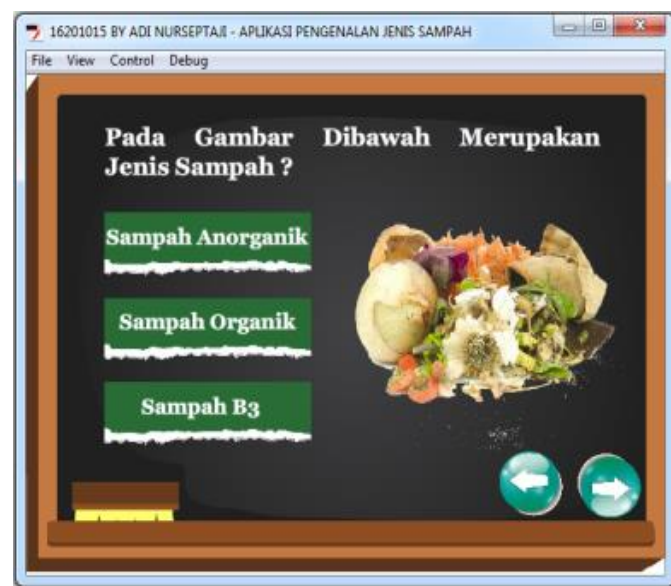

Gambar 5. User Interface latihan soal

\section{Black Box Testing}

Black-Box Testing merupakan proses yang dilakukan oleh sistem pada proses pengujian terutama terhadap aktivitas atau tindakan dari masalah-masalahnya. Testing yang dilakukan merupakan pengetesan pada penekanan keseluruhan fungsional sistem untuk mengidentifikasi proses input (Rosmiati, 2021).
Tabel 6. Tabel Pengujian Blackbox Testing

\begin{tabular}{|c|c|c|c|}
\hline INPUT & $\begin{array}{c}\text { PROSE } \\
\text { S }\end{array}$ & OUTPUT & $\begin{array}{c}\text { VALIDA } \\
\text { SI }\end{array}$ \\
\hline $\begin{array}{l}\text { Button } \\
\text { Mulai. }\end{array}$ & \multirow{3}{*}{$\begin{array}{c}\text { Menam } \\
\text { pilkan } \\
\text { menu } \\
\text { utama. }\end{array}$} & \multirow{2}{*}{$\begin{array}{l}\text { Tampil } \\
\text { halaman } \\
\text { menu } \\
\text { utama dan } \\
\text { pilihan } \\
\text { menu. }\end{array}$} & \multirow[t]{3}{*}{ Sesuai. } \\
\hline MULAI & & & \\
\hline & & & \\
\hline $\begin{array}{c}\text { Button } \\
\text { Jenis }\end{array}$ & $\begin{array}{l}\text { Menam } \\
\text { pilkan }\end{array}$ & 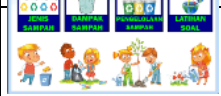 & \multirow[t]{4}{*}{ Sesuai. } \\
\hline Sampah & \multirow{3}{*}{$\begin{array}{l}\text { Pengeti } \\
\text { an } \\
\text { Jenis- } \\
\text { jenis } \\
\text { Sampah }\end{array}$} & \multirow{2}{*}{$\begin{array}{c}\text { menu } \\
\text { pengertian } \\
\text { jenis } \\
\text { sampah } \\
\text { dan pilihan } \\
\text { menu. }\end{array}$} & \\
\hline 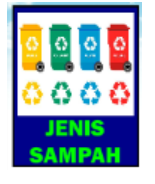 & & & \\
\hline & & $=1$ & \\
\hline $\begin{array}{c}\text { Button } \\
\text { Sampah } \\
\text { Organik. }\end{array}$ & \multirow{3}{*}{$\begin{array}{c}\text { Menam } \\
\text { pilkan } \\
\text { materi } \\
\text { pengerti } \\
\text { an jenis } \\
\text { sampah } \\
\text { organik. }\end{array}$} & 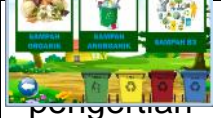 & \multirow[t]{3}{*}{ Sesuai. } \\
\hline & & $\begin{array}{l}\text { sampah } \\
\text { organik. }\end{array}$ & \\
\hline & & $\theta^{\circ} \equiv$ & \\
\hline $\begin{array}{c}\text { Button } \\
\text { Sampah } \\
\text { Anoraan }\end{array}$ & \multirow{3}{*}{$\begin{array}{c}\text { Menam } \\
\text { pilkan } \\
\text { materi } \\
\text { pengerti } \\
\text { an jenis } \\
\text { sampah } \\
\text { non- } \\
\text { organik. }\end{array}$} & $\begin{array}{c}\text { halaman } \\
\text { pengertian }\end{array}$ & \multirow{3}{*}{ Sesuai. } \\
\hline & & $\begin{array}{c}\text { sampah } \\
\text { Anorganik. }\end{array}$ & \\
\hline 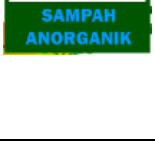 & & $\rho_{0}=E=$ & \\
\hline $\begin{array}{c}\text { Button } \\
\text { Sampah } \\
\text { B3. }\end{array}$ & \multirow{4}{*}{$\begin{array}{c}\text { Menam } \\
\text { pilkan } \\
\text { materi } \\
\text { pengerti } \\
\text { an jenis } \\
\text { sampah } \\
\text { Bahan } \\
\text { Berbah } \\
\text { aya dan } \\
\text { Beracun } \\
\text { (B3). }\end{array}$} & $\begin{array}{c}\text { halaman } \\
\text { pengertian }\end{array}$ & \multirow{4}{*}{ Sesuai. } \\
\hline $\int_{0 \rightarrow \infty}$ & & $\begin{array}{l}\text { sampan } \\
\text { B3. }\end{array}$ & \\
\hline SAMPAH B & & $5=-=$ & \\
\hline & & $8=-93$ & \\
\hline
\end{tabular}




\begin{tabular}{|c|c|c|c|}
\hline $\begin{array}{c}\text { Button } \\
\text { Dampak } \\
\text { Sampah } \\
\\
\begin{array}{c}\text { DAMPAK } \\
\text { SAMPAH }\end{array}\end{array}$ & $\begin{array}{c}\text { Menam } \\
\text { pilkan } \\
\text { materi } \\
\text { dampak } \\
\text { dari } \\
\text { penimb } \\
\text { unan } \\
\text { sampah }\end{array}$ & $\begin{array}{c}\text { Tampil } \\
\text { halaman } \\
\text { materi } \\
\text { dampak } \\
\text { dari limbah } \\
\text { sampah. } \\
\end{array}$ & Sesuai. \\
\hline $\begin{array}{c}\text { Button } \\
\text { Pengelo } \\
\text { laan } \\
\text { Sampah } \\
\\
\\
\\
\text { PENGELOLAAN } \\
\text { SAMPAH }\end{array}$ & $\begin{array}{c}\text { Menam } \\
\text { pilkan } \\
\text { materi } \\
\text { bagaim } \\
\text { ana } \\
\text { cara } \\
\text { mengel } \\
\text { ola } \\
\text { sampah }\end{array}$ & $\begin{array}{c}\text { materi } \\
\text { pengelolaa } \\
\text { n limbah } \\
\text { sampah. } \\
\end{array}$ & Sesuai. \\
\hline $\begin{array}{c}\text { Button } \\
\text { Latihan } \\
\text { Soal. }\end{array}$ & $\begin{array}{c}\text { Menam } \\
\text { pilkan } \\
\text { soal } \\
\text { latihan } \\
\text { tentang } \\
\text { limbah } \\
\text { sampah } \\
\text {. }\end{array}$ & $\begin{array}{c}\text { Tampil } \\
\text { latihan soal } \\
\text { dan pilihan } \\
\text { iawaban. } \\
\\
\end{array}$ & Sesuai. \\
\hline & $\begin{array}{c}\text { Pilihan } \\
\text { jawaban } \\
\text { ketika } \\
\text { penggu } \\
\text { na } \\
\text { latihan } \\
\text { soal, } \\
\text { ketika } \\
\text { jawaban } \\
\text { yang } \\
\text { dipilh } \\
\text { benar } \\
\text { maka } \\
\text { akan } \\
\text { tampil } \\
\text { halama } \\
\text { n benar, } \\
\\
\text { Ketika } \\
\text { penggu } \\
\text { na } \\
\text { memilih } \\
\text { jawaban } \\
\text { yang } \\
\text { salah } \\
\text { maka } \\
\text { akan } \\
\text { tampil } \\
\text { halama }\end{array}$ & $\begin{array}{c}\text { Tampil } \\
\text { halaman } \\
\text { jawaban } \\
\text { salah. }\end{array}$ & Sesuai. \\
\hline
\end{tabular}

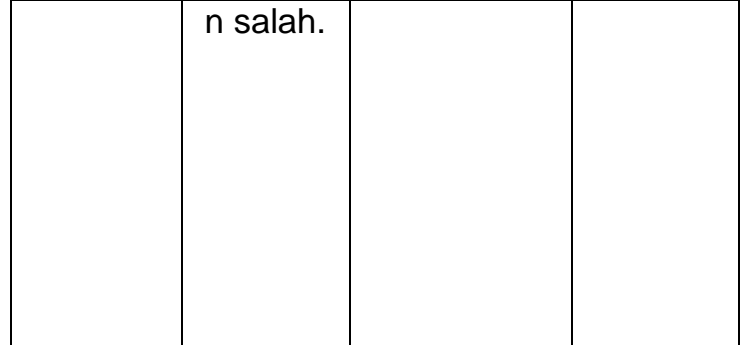

\section{Kesimpulan}

Berdasarkan pada skripsi yang telah penulis lakukan tentang media pembelajaran animasi interaktif pengenalan jenis sampah berdasarkan jenisnya, terdapat kesimpulan yang bisa diambil diantaranya akan diuraikan sebagi berikut ini:

1. Rancangan aplikasi yang telah dikembangkan pada skripsi ini mengenai media pembelajaran animasi interaktif mampu meningkatan minat tentang edukasi pembelajaran limbah sampah berdasarkan jenisnya karena aplikasi yang dirancangan menampilkan animasi gambar dan juga suara yang dapat menarik pada saat proses pembelajaran edukasi limbah sampah, sehingga edukasi yang disampaikan tidak membosankan dapat meningkatan motivasi serta semangat dalam hal pemahaman limbah sampah.

2. Aplikasi yang dikembangkan melingkupi materi soal latihan sehingga dapat menunjang dan meningkatkan sarana media pembelajaran serta kualitas kegiatan edukasi mengenai limbah sampah.

3. Aplikasi yang lebih interaktif dirancangan dapat menambah kreativitas pada saat proses edukasi pembelajaran.

4. Aplikasi media pembelajaran yang dirancang menggunakan teknologi sehingga dapat memberikan kemudahan informasi edukasi yang disampaikan.

5. Aplikasi yang dirancang dapat memperkenalan media pembelajaran berbasis teknologi informasi.

\section{Referensi}

Anggara, D. A., Harianto, W., \& Aziz, A. (2021). Prototipe Desain User Interface Aplikasi Ibu Siaga Menggunakan Lean Ux. Kurawal-Jurnal Teknologi, Informasi dan Industri, 4(1), 58-74.

Annisa, N., Saragih, A. H., \& Mursid, R. (2019). Pengembangan Media Pembelajaran Interaktif Pada Mata Pelajaran Bahasa Inggris. Jurnal 
Teknologi Informasi \& Komunikasi Dalam Pendidikan, 5(2), 210-221. https://doi.org/10.24114/jtikp.v5i2.1259 9

Kurniawarsih, M., \& Rusmana, I. M. (2020). Pengembangan Media Pembelajaran Komik Matematika Siswa Kelas IV Sekolah Dasar Berbasis Budaya. Jurnal IImiah Pendidikan Matematika, Matematika Dan Statistika, 1(1), 3948. https://doi.org/10.46306/lb.v1i1

Meilano, R., \& Damanik, F. (2021). Pengembangan Sistem Informasi Persediaan Barang dengan Metode Waterfall. Jurnal Elektronika Listrik dan Teknologi Informasi Terapan, 2(2), 3034.

Rasyid \& Rohani. (2018). Manfaat Media Dalam Pembelajaran. Axiom: Jurnal Pendidikan Dan Matematika, 148, 148-162.

Regina, F. R. E. (2020). Perancangan Media Pembelajaran Interaktif Mengenai Klasifikasi Dan Pengolahan Sampah Menurut Jenisnya Berbasis 2D. Jurnal Mitra Pendidikan, 4(1), 485-498.

Rezeki, S., \& Ishafit, I. (2017). Pengembangan Media Pembelajaran Interaktif untuk Sekolah Menengah Atas Kelas XI pada Pokok Bahasan Momentum. Jurnal Penelitian \& Pengembangan Pendidikan Fisika, 3(1), https://doi.org/10.21009/1.03104

Robby Andry, P. M. (2020). Aplikasi Pembelajaran Interaktif Mengenal Komputer Berbasis Android Studi Pada Sdn 01 Tegalgede. EProsiding Sistem Informasi (POTENSI), 1(1), 89-98.

Rosmiati. (2021). Analisis Dan Pengujian Sistem Menggunakan Black Box Testing Equivalence Partitioning. Jurnal Sains Komputer Dan Teknologi Informasi, 3(2), 56-63.

Rustandi, R., \& Mauliana, P. (2020). Media Pembelajaran Pengenalan Dan Pengelompokkan Hewan Berbasis Multimedia Interaktif Studi Pada Sdn 01 Tegalgede. EProsiding Sistem Informasi (POTENSI), 1(1), 52-59.

Setiawan Mardian D \& Wiguna Wildan. (2020). Media Pembelajaran Bahasa Inggris Berbasis Mobile Menggunakan Unity Di Tk Ryadlol Hasanah. EProsiding Teknik Informatika (PROTEKTIF), 1(1), 208-217.

Walhidayat, W., Yuhelmi, Y., \& Devega, M. (2019). Perancangan Animasi Robot
3D Sebagai Sarana Promosi. Jurnal Teknologi Informasi Mura, 11(02), 103-111. https://doi.org/10.32767/jti.v11i02.667

Zaini, B., \& Saputri, M. P. (2017). Pengembangan Media Pembelajaran Interaktif Contextual Teaching and Learning (CTL) Untuk Siswa Pendidikan Anak Usia Dini (PAUD) di PAUD SAHABAT. Http://Journal.Unj.Ac.Id/Unj/Index.Php/ Pinter, 1(2), 90-100. 